\section{Cureus}

Received 10/01/2015

Review began 10/27/2015

Review ended 03/26/2016

Published 04/01/2016

\section{(C) Copyright 2016}

Johnson et al. This is an open access article distributed under the terms of the Creative Commons Attribution License CC-BY 3.0., which permits unrestricted use, distribution, and reproduction in any medium, provided the original author and source are credited.

\title{
Brain Metastases as Presenting Feature in 'Burned Out' Testicular Germ Cell Tumor
}

\author{
Kate Johnson ${ }^{1}$, Bryan Brunet ${ }^{2}$ \\ 1. Radiation Oncology, Cancer Care Manitoba, University of Manitoba, Canada 2. Radiation Oncology, \\ Saskatoon Cancer Center
}

$\square$ Corresponding author: Kate Johnson, kate.johnson@usask.ca

Disclosures can be found in Additional Information at the end of the article

\section{Abstract}

Testicular germ cell tumors (TGCTs) are the most common malignancy in males aged 20 to 39, and the incidence is increasing. TGCTs have a tendency to grow rapidly with a high risk of metastatic spread. TGCTs generally present with a palpable testicular mass, yet may present less commonly with symptoms arising from metastatic disease.

A 24-year-old otherwise healthy male presented with progressive headaches. Initial imaging reported a single mass in the right frontal lobe. Complete surgical resection revealed suspicion for metastatic poorly differentiated carcinoma with an inconclusive immunohistochemical profile. Further staging scans revealed pulmonary and pelvic tumor deposits. Tumor markers with alpha-fetoprotein, beta-human chorionic gonadotropin, and lactate dehydrogenase were not elevated. Follow-up cranial magnetic resonance imaging revealed intracranial disease progression and he underwent whole brain radiation therapy. Additional outside pathology consultation for chromosomal analysis revealed features consistent with a TGCT. A scrotal ultrasound revealed a minimally atrophic right testicle. With evidence supporting the potential for response to chemotherapeutic treatment in TGCT, the patient was started on cisplatin and etoposide. Bleomycin was planned for the second cycle of chemotherapy if his pulmonary function improved.

A salient feature of all invasive TGCTs is a gain in material in the short arm of chromosome 12, and is diagnostic if present. Although the initial pathology revealed a non-diagnostic metastatic tumor, further testing revealed amplification of chromosome 12p. The examination of poorly differentiated carcinomas of an unknown primary site using light microscopy and immunohistochemical profiling alone may be inadequate, and should undergo molecular chromosomal analysis.

This case is presented for its unconventional presentation and rarity of occurrence. It brings forward the discussion of both the commonality of TGCT in young male adults, as well as the anomaly of a 'burned out' phenomenon. With unreliable tumor markers, nonspecific symptoms, and pathological findings, 'burned out' TGCTs may account for a challenging diagnosis in a variety of cases, especially with the presenting symptom arising from a less common metastatic site. This case adds to the increasing literature on a rare entity of the 'burned out' TGCT, and upon literature review, presents itself as the first reported case presenting with brain metastasis.

Categories: Oncology, Pathology, Urology

Keywords: brain metastasis, regressed, 'burned out' phenomenon, testicular tumour, germ cell tumour, chromosome $12 \mathrm{p}$, case report 


\section{Introduction}

Testicular germ cell tumors (TGCTs) are the most common malignancy diagnosed in males aged 20 to 39, and the incidence is increasing [1-3]. TGCTs have a tendency to grow rapidly with a high risk of metastatic spread. TGCTs generally present with a palpable testicular mass, yet, less commonly may present with symptoms arising from metastatic disease. Specifically, TGCTs have a propensity to metastasize to retroperitoneal lymph nodes, lungs, liver, bones, and less frequently, to the brain [4].

The phenomenon of a primary TGCT outgrowing its blood supply and undergoing autoinfarction has been described as a 'burned out' TGCT. The regressed testicular lesion is not appreciable on physical exam, and spontaneous regression occurs without treatment [5]. Despite the regression of the primary testicular tumor, approximately $50 \%$ of 'burned out' primary testicular tumors continue to harbor malignant cells and distant metastatic disease can progress [6-7]. A 'burned out' TGCT can arise, regress, and metastasize within the same testicle. Cases within the literature describe pathological evidence of tumor regression of a testicular mass with a focus of GCT within a clinically unremarkable testicle $[4,8]$. This can lead to difficulty in making a diagnosis as the metastasis can be mistaken for a primary tumor.

Imaging can be helpful in making the diagnosis, with scrotal ultrasonography revealing evidence of a regressed tumor. Possible findings consist of a hypoechoic area, atrophic testicle, or microcalcifications [7-8]. Macroscopic evidence of a fibrotic scar in the parenchyma and microscopic findings of intratubular germ cells or seminomatous foci may be seen on pathological evaluation [9-11].

Of significance, extra-gonadal germ cell tumors (EGCT) are a known entity that also present with biochemistry and histological findings of a germ cell tumor in the absence of primary testicular or ovarian tumor. However, EGCT are differentiated from 'burned out' TGCT by their characteristic midline location, from the pineal gland to the coccyx. Furthermore, in EGCT no radiologic nor pathologic evidence of a primary malignancy is present in the primary reproductive organs [12].

Chemotherapeutic strategies implemented in the 1970s for the treatment of advanced stage TGCTs represents a paradigm shift to a curable disease [13-15]. Here we discuss a rare case that highlights the challenges of diagnosing a 'burned out' TGCT.

\section{Case Presentation}

A 24-year-old previously healthy male presented with progressive nausea, vomiting, visual changes, and memory impairment. His only significant finding on history was a strong family history of factor $\mathrm{V}$ Leiden mutation. The physical exam was grossly unremarkable. The initial magnetic resonance imaging (MRI) reported a single mass in the right frontal lobe (Figure 1). 


\section{Cureus}

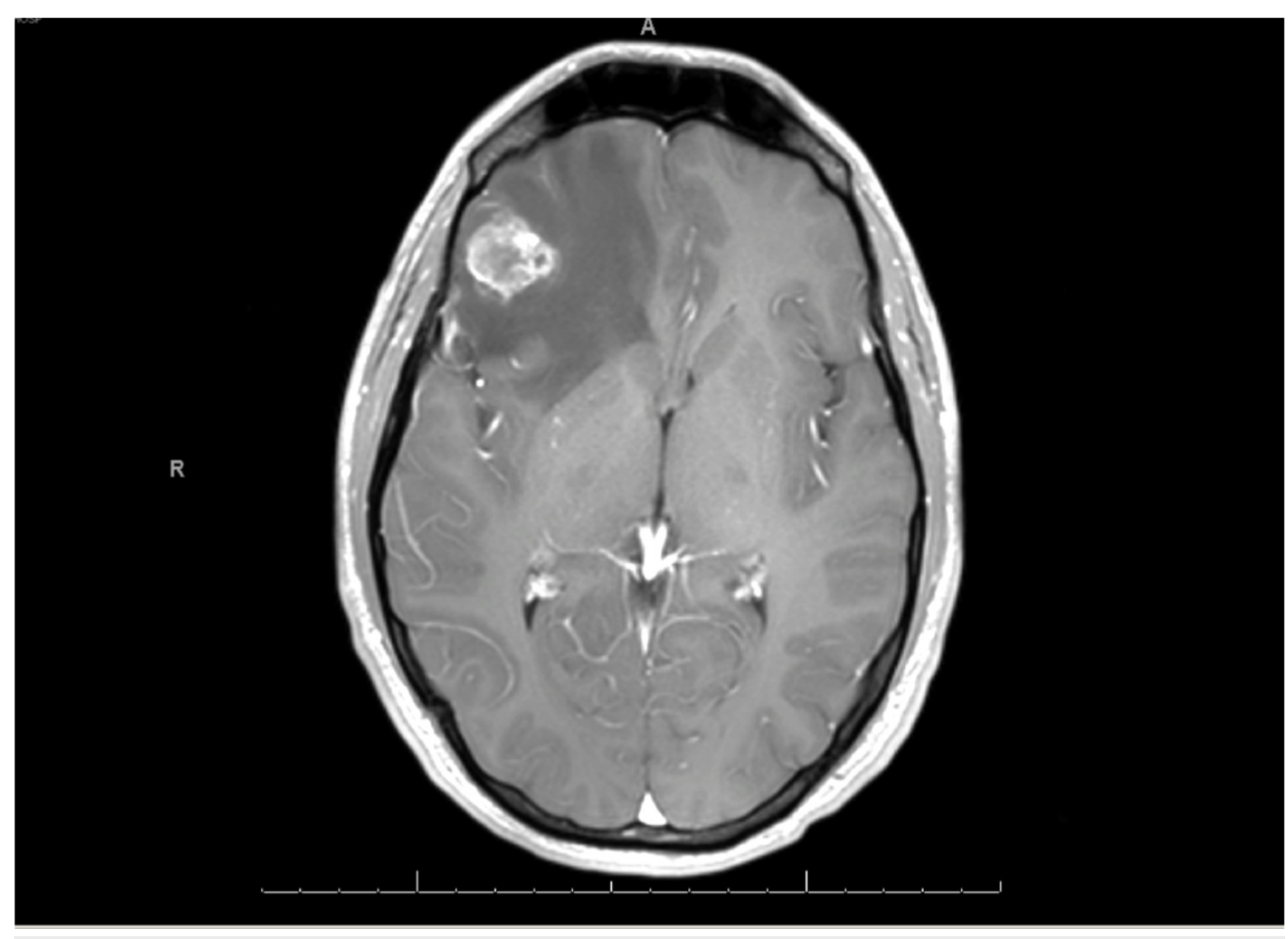

\section{FIGURE 1: Initial Brain MRI}

Single intra-axial heterogeneously enhancing mass in the inferior aspect of the right frontal lobe.

With high suspicion for primary brain tumor, total resection of the intracranial lesion was performed and revealed a metastatic, poorly differentiated carcinoma with an inconclusive immunohistochemical profile.

Staging investigations with computed tomography (CT) and positron emission tomographic (PET) scans revealed pulmonary and pelvic tumor deposits. A scrotal ultrasound revealed a minimally atrophic right testicle with no further abnormalities detected. A follow-up cranial MRI revealed enhancement in the surgical bed and new metastatic foci (Figures 2, 3). 


\section{Cureus}

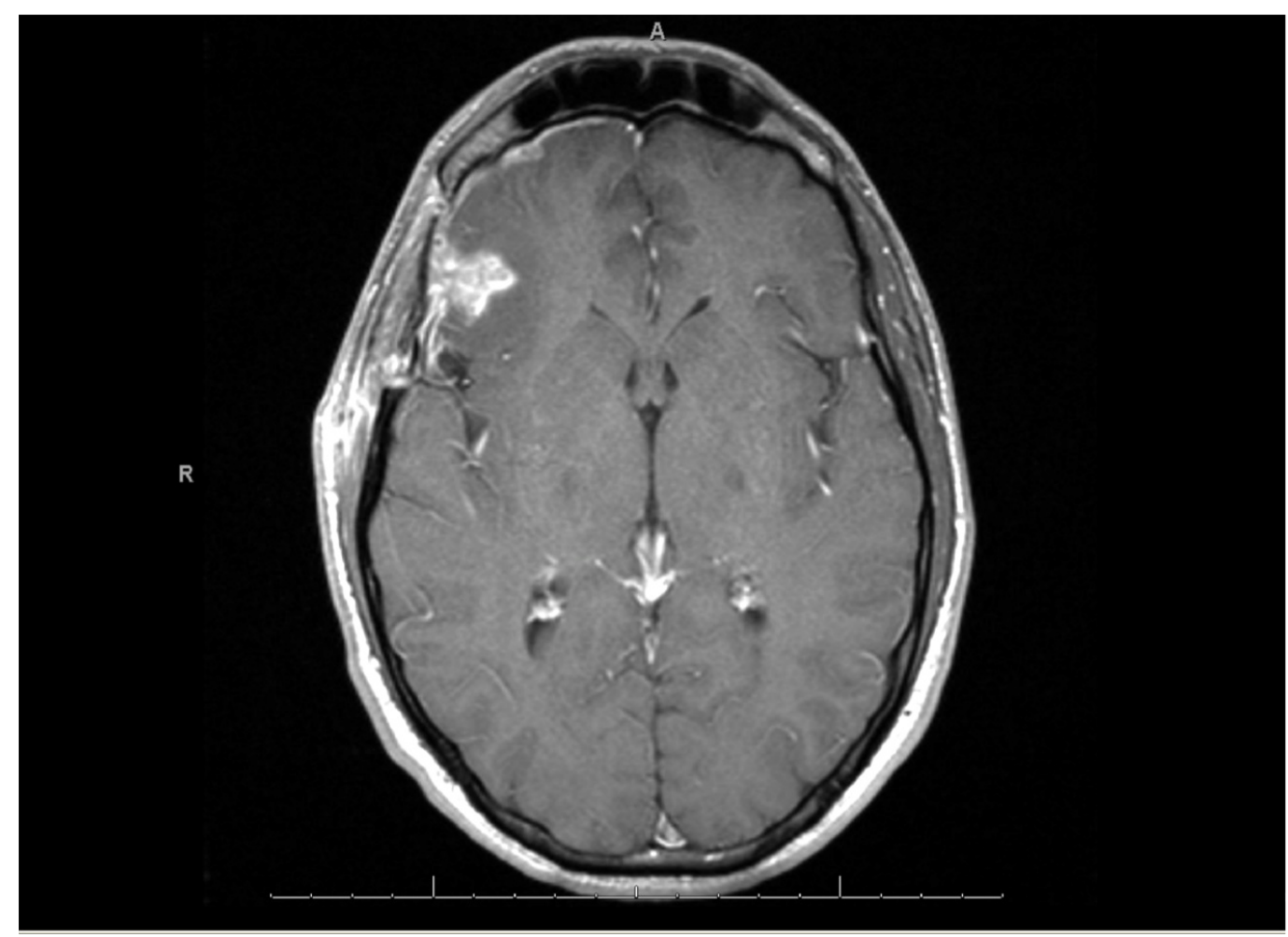

FIGURE 2: MRI One Month Post-Resection

Increased enhancement in the surgical bed.

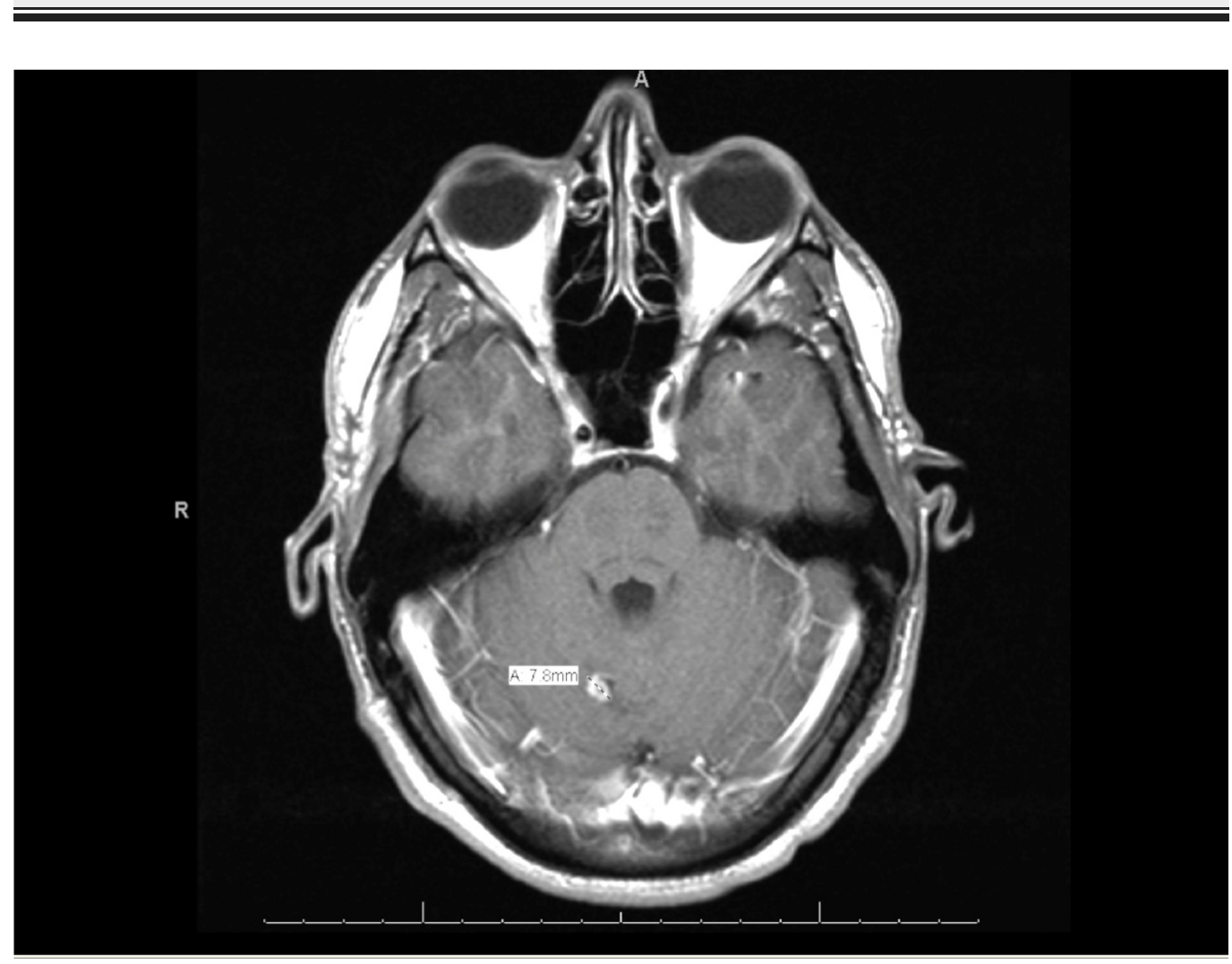

FIGURE 3: MRI One Month Post-Resection

New definite enhancing foci compatible with metastatic foci. 


\section{Cureus}

Pathological and imaging findings were consistent with metastatic carcinoma with progressive brain lesions from an unestablished primary focus. At this time the brain lesions were increasingly symptomatic. Further treatment options with chemotherapy and whole brain radiation therapy (WBRT) were discussed with the patient. The patient refused palliative intent chemotherapeutic intervention for unknown primary, but agreed to WBRT with a prescribed dose of 30 gray in 10 fractions delivered. Subsequent to this, additional remote pathological consultation with chromosomal analysis revealed isochrome $12 \mathrm{p}$ amplications, consistent with a TGCT. Tumor markers with alpha-fetoprotein (aFP), beta-human chorionic gonadotropin (BhCG), and lactate dehydrogenase (LDH) were not elevated. With evidence supporting the potential for response to chemotherapeutic intervention in TGCT, the patient was started on cisplatin and etoposide, with the plan to include bleomycin in subsequent cycles if his pulmonary function improved [14-16]. Unfortunately the patient's clinical course consisted of progressive brain metastases (Figure 4), seizures, and pulmonary embolism.

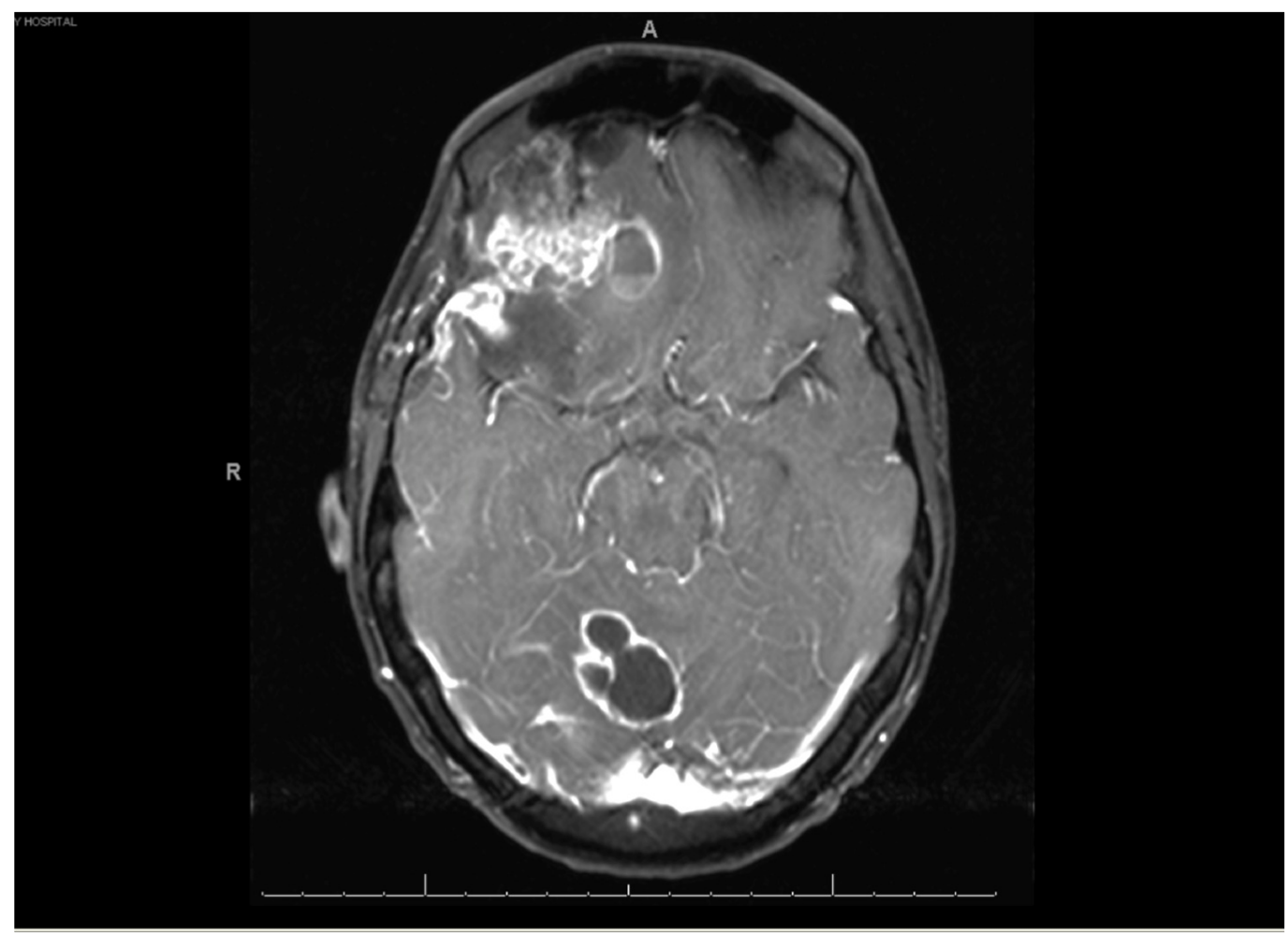

\section{FIGURE 4: MRI Five Months After Initial Presentation}

Marked progression in a multiple ring-enhancing lesions with vasogenic edema.

He rapidly deteriorated before receiving a full course of treatment and succumbed to his disease only five months after initial presentation. Informed consent was obtained from the patient initially and from the patient's family after he passed away.

\section{Discussion}

\section{Literature review}




\section{Cureus}

English publications of 'burned out' TGCT case reports were identified from Medline and EMBASE databases via OVID engine without restrictions on year of publication. The keywords were "germ cell tumor," "burned out phenomenon," and "testicular tumor." Additional studies were identified from reference lists of retrieved papers and review articles. Studies that did not discuss primary testicular origin were excluded. The search yielded 38 results and each abstract was reviewed. A total of 27 articles were thoroughly reviewed and 79 cases of 'burned out' TGCTs were identified. The presenting sites, age of patient, tumor markers, histology, treatments employed, and outcomes were tabulated (Table 1) [5, 7-8, 17-40].

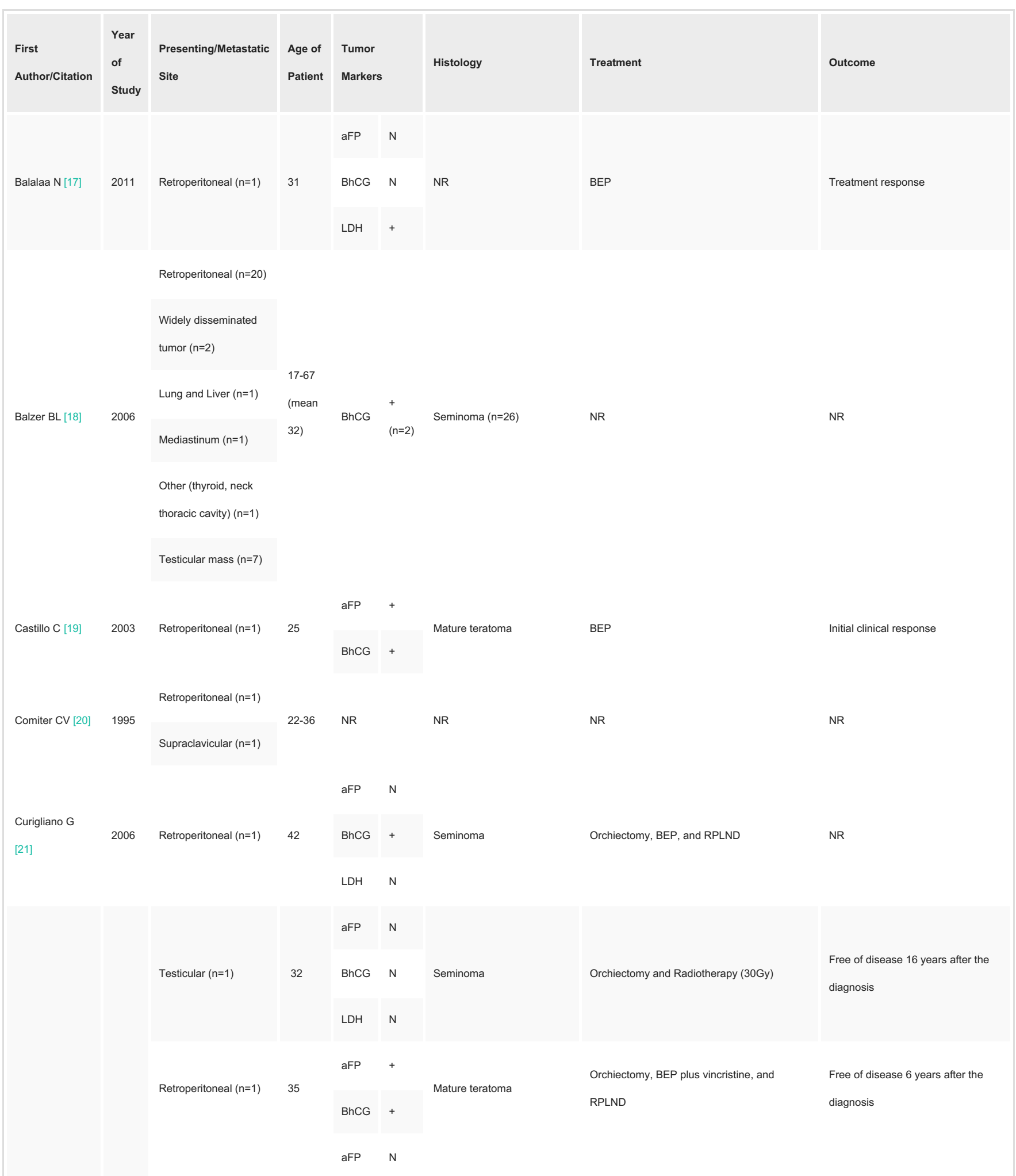




\section{Cureus}

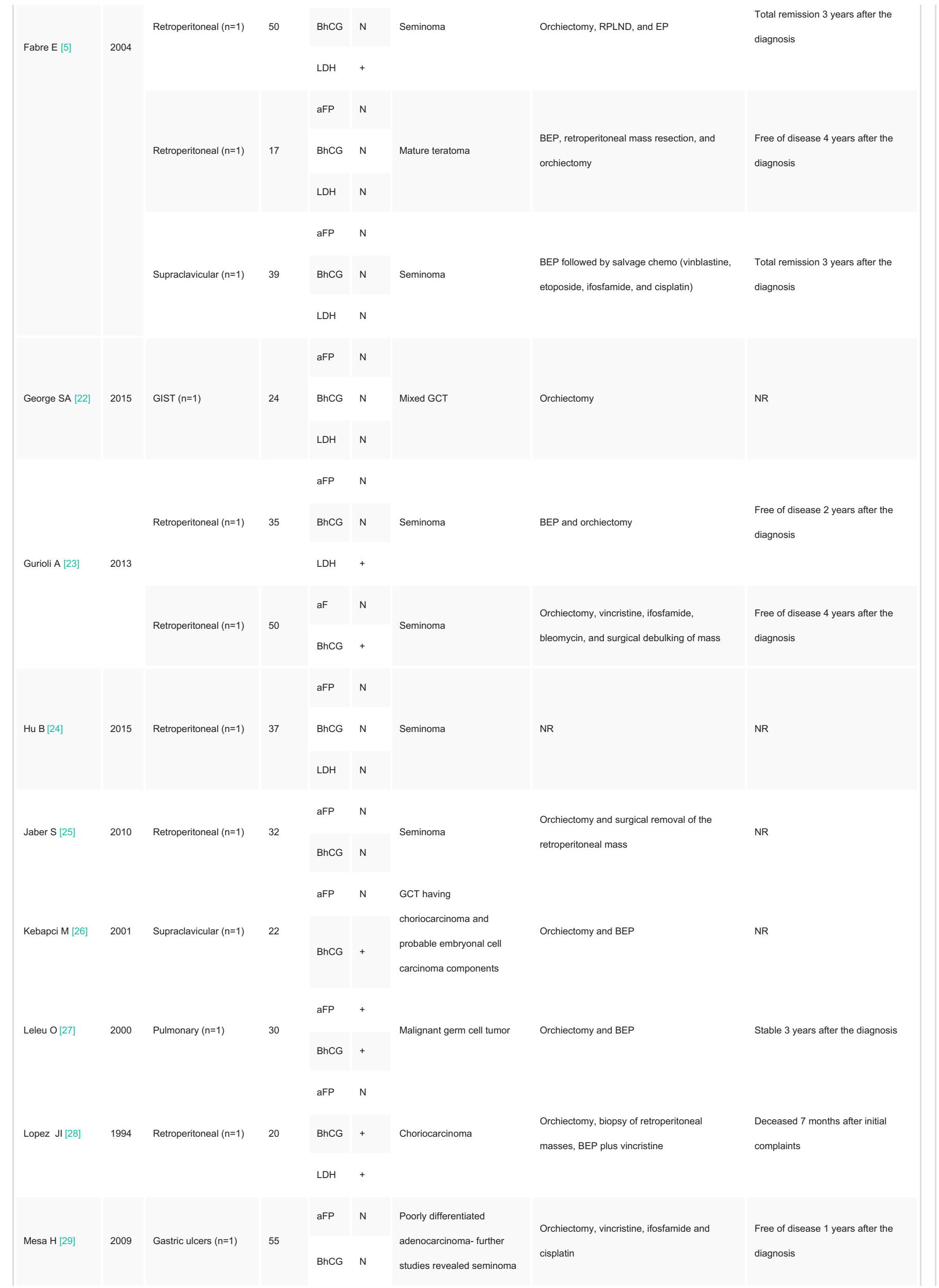




\section{Cureus}

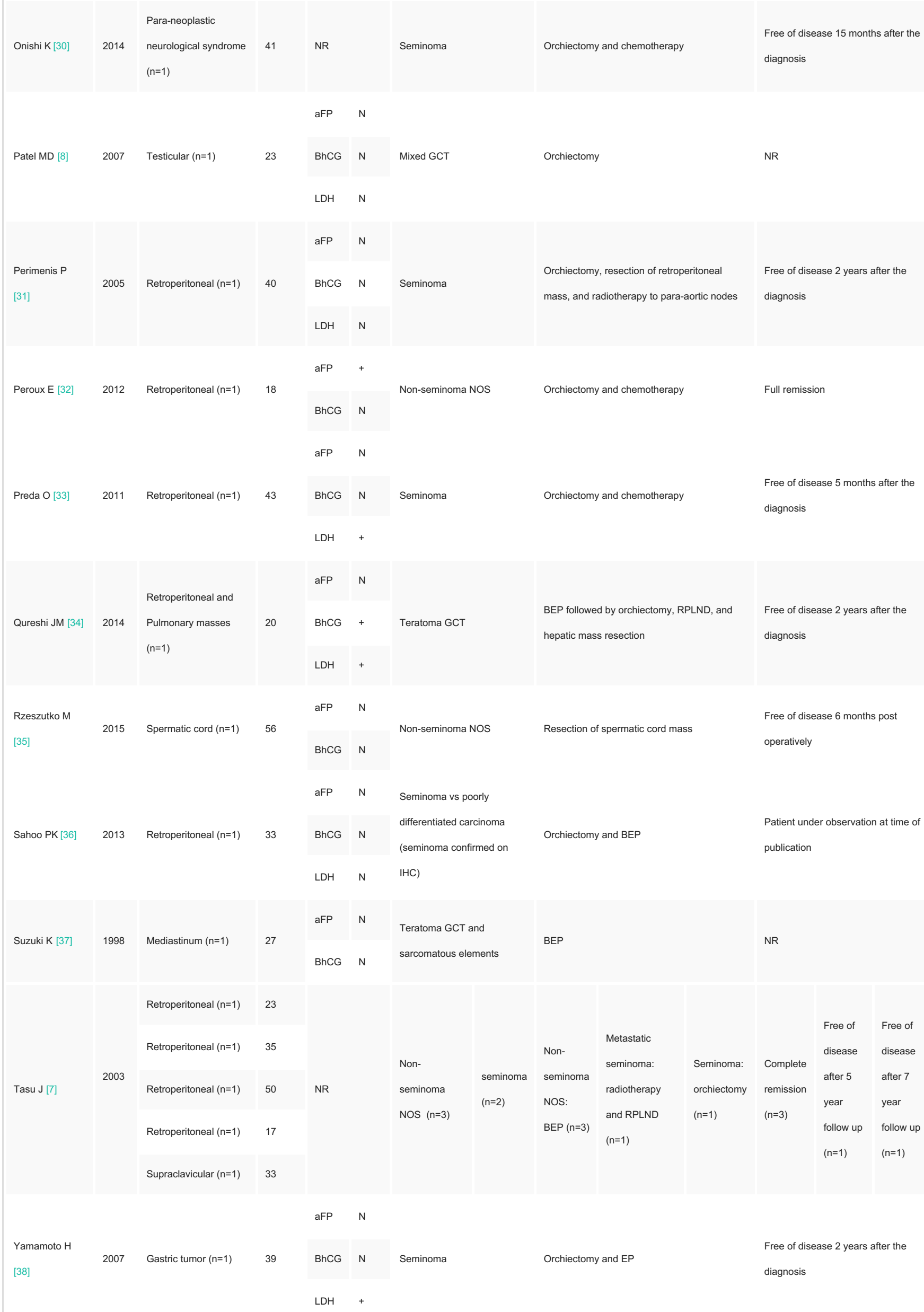

BEP

NR

\section{diagnosis}

Resection of spermatic cord mass

LDH $\quad+$ 


\section{Cureus}

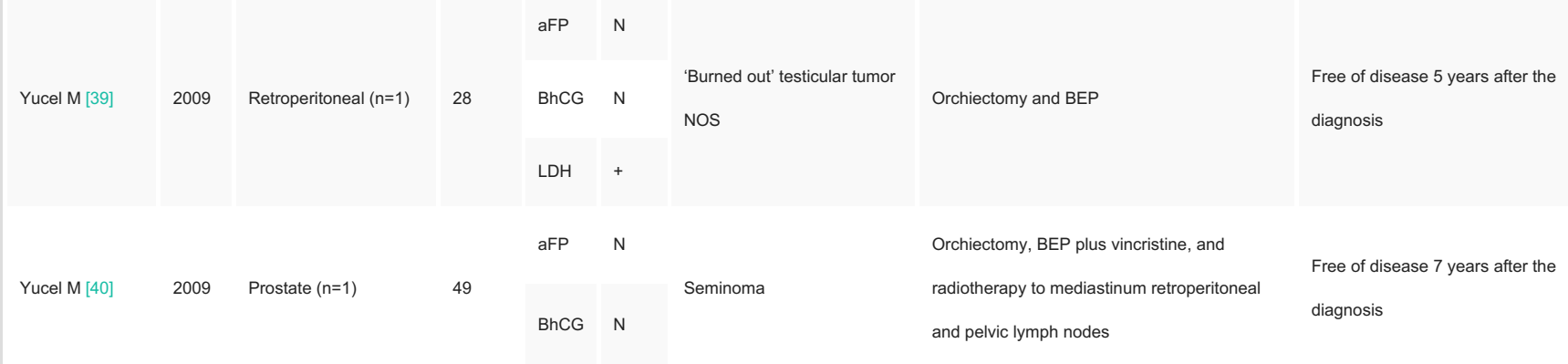

\section{TABLE 1: Reported Cases of 'Burned Out' TGCT}

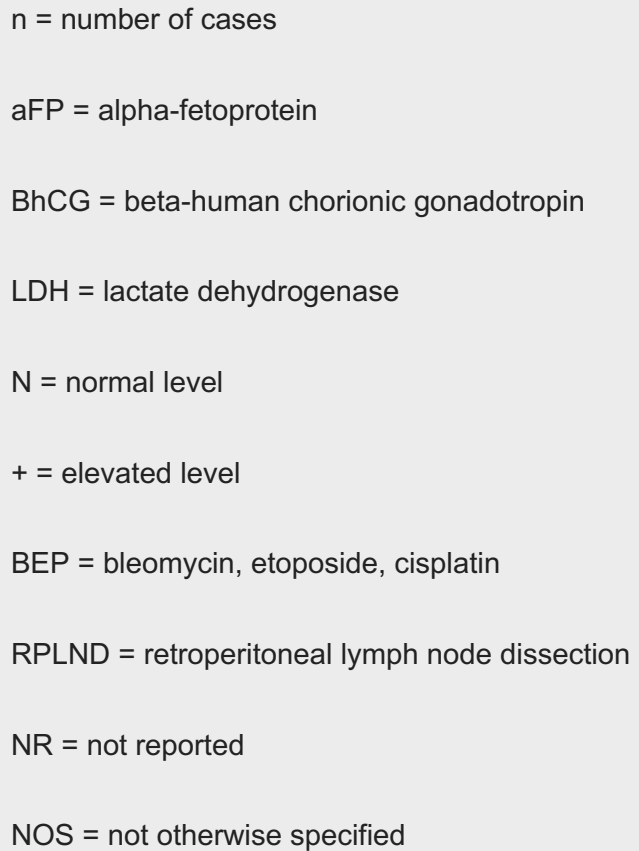

\section{Results}

The sites of symptomatic metastasis identified were retroperitoneal (51.9\%), testicular (12.7\%), mediastinal (3.8\%), pulmonary (3.8\%), gastric (3.8\%), and others (24.1\%) consisting of prostate, supraclavicular, head and neck, and widely disseminated. The average patient age at presentation was 32.7 years old. Tumor markers were not found to be consistently elevated, with only $12.7 \%, 10.2 \%$, and $5.1 \%$ of the cases found to be increased for BhCG, aFP, and LDH respectively. The most common treatment employed was orchiectomy with chemotherapy (57.5\%), followed by chemotherapy alone (32.5\%). Radiation therapy was utilized in four (10\%) cases, all of which were seminoma $[5,7,31,40]$. The majority of reported cases had a good treatment response with only one reported death in the literature [28]. Tabulated case details are summarized in Table 2 [5, 7-8, 17-40].

\begin{tabular}{|c|c|c|c|c|c|c|c|c|c|c|c|}
\hline $\begin{array}{l}\text { Presenting Site of 'Burned Out' } \\
\text { TGCT }\end{array}$ & $\begin{array}{l}\text { Total } \\
\text { Cases }\end{array}$ & $\begin{array}{l}\text { Age } \\
\text { (Mean, } \\
\text { Range) }\end{array}$ & +BhCG & +aFP & +LDH & $\begin{array}{l}\text { Orch } \\
\text { Alone }\end{array}$ & $\begin{array}{l}\text { Chemo } \\
\text { Alone }\end{array}$ & $\begin{array}{l}\text { Orch + } \\
\text { Chemo }\end{array}$ & $\begin{array}{l}\text { Radiation } \\
\text { Therapy } \\
\text { Included }\end{array}$ & $\begin{array}{l}\text { Treatment } \\
\text { Unknown }\end{array}$ & $\begin{array}{l}\text { Treatment Response, } \\
\text { Death, Outcome } \\
\text { Unknown }\end{array}$ \\
\hline Retroperitoneal & 41 & $32(17-67)$ & & & & & 4 & 9 & 2 & 21 & $15,1,26$ \\
\hline
\end{tabular}




\section{Cureus}

\begin{tabular}{|c|c|c|c|c|c|c|c|c|c|c|c|c|}
\hline & Seminoma & & & & & & & 4 & & 2 & & \\
\hline & NSGCT & & & & & & & & & & & \\
\hline \multirow[t]{3}{*}{ Testicular } & & 10 & $33,(23-56)$ & & & & 2 & & & 1 & 7 & $2,0,8$ \\
\hline & Seminoma & & & & & & & & & 1 & & \\
\hline & NSGCT & & & & & & 2 & & & & & $0,0.3$ \\
\hline \multirow[t]{3}{*}{ Mediastinum } & & 3 & $\begin{array}{l}30.3(27- \\
32)\end{array}$ & & & & & 1 & & & 2 & \\
\hline & Seminoma & & & & & & & & & & & \\
\hline & NSGCT & & & & & & & 1 & & & & \\
\hline \multirow[t]{3}{*}{ Pulmonary } & & 3 & $\begin{array}{l}27.3(20- \\
32)\end{array}$ & & & & & & 2 & & & $2,0,1$ \\
\hline & Seminoma & & & & & & & & & & & \\
\hline & NSGCT & & & & & & & & 2 & & & \\
\hline \multirow[t]{3}{*}{ Gastric } & & 3 & $39(24-55)$ & & & & & 1 & 2 & & & \\
\hline & Seminoma & & & & & & & & 2 & & & \\
\hline & NSGCT & & & & & & & & & & & \\
\hline \multirow[t]{3}{*}{ Other } & & 19 & $32(20-49)$ & & & & & 1 & 3 & 1 & 8 & $4,0,13$ \\
\hline & Seminoma & & & & & & & & 1 & 1 & & \\
\hline & NSGCT & & & & & & & 1 & 2 & & & \\
\hline \multirow[t]{4}{*}{ Total } & & 79 & $\begin{array}{l}32.7(17- \\
67)\end{array}$ & 10 & 4 & 8 & 4 & 13 & 16 & 4 & 38 & $23,1,51$ \\
\hline & Seminoma & & & & 0 & 4 & & & & 4 & & \\
\hline & NSGCT & & & & 4 & 2 & & & & & & \\
\hline & Other/unknown & & & & & 2 & & & & & & \\
\hline
\end{tabular}

\section{TABLE 2: Summary of 'Burned Out' TGCT Cases}

NSGCT $=$ non-seminomatous germ cell tumors

$+\mathrm{BhCG}=$ elevated beta-human chorionic gonadotropin level

$+\mathrm{aFP}=$ elevated alpha-fetoprotein level

$\mathrm{LDH}=$ elevated lactate dehydrogenase level

Orch= orchiectomy 


\section{Case discussion}

A salient feature of all invasive TGCTs is a gain in material in the short arm of chromosome 12, and is diagnostic if present [41]. Although the initial pathology revealed a non-diagnostic metastatic tumor, further testing revealed an amplification of chromosome $12 p$ leading to the diagnosis of TGCT. This suggests that the examination of poorly differentiated carcinomas of an unknown primary site using light microscopy and immunohistochemical profiling may be inadequate, and should undergo additional testing modalities with molecular chromosomal analysis [41-42].

The behavior and aggressive nature of the tumor discussed throughout this case combines the complexity of the evolving field of tumor biology and unique patient characteristics. Interestingly, the patient had a confirmed family history of factor V Leiden mutation. It has been suggested that clotting factor polymorphisms such as factor V Leiden are associated with cancer onset and progression. The theoretical mechanism behind such adverse effects stems from the involvement of tissue factor and thrombin in tumor angiogenesis, which is essential for tumor growth and metastasis [43]. Furthermore, such factors may contribute to a more radio-resistant tumor profile despite advanced diagnostic techniques and treatment modalities. Thus, this case reflects the arising need for further research to explore the dynamic interplay of tumor biology and patient characteristics for targeting tumor response.

\section{Conclusions}

This case is presented for its unconventional presentation, rarity of occurrence, and difficulty in diagnosis. It brings forward the discussion of both the commonality of TGCT in young male adults, as well as the anomaly of a 'burned out' TGCT. With unreliable tumor markers, nonspecific symptoms, and pathological findings, the 'burned out' phenomenon accounts for a challenging diagnosis, particularly with the presenting symptom arising from a less common metastatic site. This case adds to the increasing literature on the rare entity of the 'burned out' TGCT, and upon literature review, presents itself as the first reported case presenting with brain metastasis. By establishing a strong foundation of 'burned out' TGCT in the literature leading to familiarity of the diagnostic process, a deeper understanding into medical management may arise.

\section{Additional Information Disclosures}

Human subjects: Consent was obtained by all participants in this study. Consent for the use of case details with intent of publication was obtained from the individual described in the case study. Consent was discussed and documented by the first author of the case report. As the patient unfortunately was deceased at the time of publication, further written consent was also obtained by the family of the patient. . Conflicts of interest: In compliance with the ICMJE uniform disclosure form, all authors declare the following: Payment/services info: All authors have declared that no financial support was received from any organization for the submitted work. Financial relationships: All authors have declared that they have no financial relationships at present or within the previous three years with any organizations that might have an interest in the submitted work. Other relationships: All authors have declared that there are no other relationships or activities that could appear to have influenced the submitted work.

\section{References}


1. International Germ Cell Cancer Collaborative Group: International germ cell consensus classification: a prognostic factor-based staging system for metastatic germ cell cancers. J Clin Oncol. 1997, 15:594-603.

2. Surveillance, Epidemiology and End Result Program: SEER stat fact sheets: testis cancer. National Cancer Institute. (2015). Accessed: September 1, 2015: http://seer.cancer.gov/statfacts/html/testis.html.

3. McGlynn KA, Devesa SS, Sigurdson AJ, Brown LM, Tsao L, Tarone RE: Trends in the incidence of testicular germ cell tumors in the United States. Cancer. 2003, 97:63-70. 10.1002/cncr.11054

4. Bosl GJ, Motzer RJ: Testicular germ-cell cancer. N Engl J Med. 1997, 337:242-254. 10.1056/NEJM199707243370406

5. Fabre E, Jira H, Izard V, Ferlicot S, Hammoudi Y, Theodore C, Di Palma M, Benoit G, Droupy S: 'Burned-out' primary testicular cancer. BJU Int. 2004, 94:74-78. 10.1111/j.1464410X.2004.04904.X

6. Azzopardi JG, Mostofi FK, Theiss EA: Lesions of testes observed in certain patients with widespread choriocarcinoma and related tumors. The significance and genesis of hematoxylin-staining bodies in the human testis. Am J Pathol. 1961, 38:207-225.

7. Tasu J, Faye N, Eschwege P, Rocher L, Bléry M: Imaging of burned-out testis tumor: five new cases and review of the literature. J Ultrasound Med. 2003, 22:515-521.

8. Patel MD, Patel BM: Sonographic and magnetic resonance imaging appearance of a burnedout testicular germ cell neoplasm. J Ultrasound Med. 2007, 26:143-146.

9. Choyke PL, Hayes WS, Sesterhenn IA: Primary extragonadal germ cell tumors of the retroperitoneum: differentiation of primary and secondary tumors. Radiographics. 1993, 13:1365-1375.

10. Savatovsky I, Paugam B, Piekarski JD: Retroperitoneal lymph node metastasis of an infraclinical testicular seminoma (author's transl). [Article in French]. J Urol (Paris). 1981, $87: 235-237$

11. Bohle A, Studer UE, Sonntag RW, Scheidegger JR: Primary or secondary extragonadal germ cell tumors?. J Urol. 1986, 135:939-943.

12. Albany C, Einhorn LH: Extragonadal germ cell tumors: clinical presentation and management . Curr Opin Oncol. 2013, 25:261-265.

13. Einhorn LH: Curing metastatic testicular cancer. Proc Natl Aca Sc USA. 2002, 99:4592-4595. 10.1073/pnas.072067999

14. Einhorn L, Williams S: Chemotherapy of disseminated testicular cancer. a random prospective study. Cancer. 1980, 46:1339-1344. 10.1002/1097-0142(19800915)46:6<1339::AIDCNCR2820460607>3.0.CO;2-J

15. Kollmannsberger C, Nichols C, Bamberg M, Hartmann JT, Schleucher N, Beyer J, Schöfski P, Derigs G, Rüther U, Böhlke I, Schmoll HJ, Kanz L, Bokemeyer C: First-line high-dose chemotherapy +/- radiation therapy in patients with metastatic germ-cell cancer and brain metastases. Ann Oncol. 2000, 11:553-559. 10.1023/A:1008388328809

16. Bokemeyer C, Nowak P, Haupt A, Metzner B, Köhne H, Hartmann JT, Kanz L, Schmoll HJ: Treatment of brain metastases in patients with testicular cancer . J Clin Oncol. 1997, 15:14491454.

17. Balalaa N, Salman M, Hassen W: Burned-out testicular tumor: a case report. Case Rep Oncol. 2011, 4:12-15. 10.1159/000324041

18. Balzer BL, Ulbright TM: Spontaneous regression of testicular germ cell tumors: an analysis of 42 cases. Am J Surg Pathol. 2006, 30:858-865. 10.1097/01.pas.0000209831.24230.56

19. Castillo C, Krygier G, Carzoglio J, Cepellini Magariños R, Cepellini Olmos R, Jubín J, Sabini G: Gastrointestinal bleeding as the first manifestation of a burned-out tumour of the testis . Clin Transl Oncol. 2005, 7:458-463. 10.1007/BF02716597

20. Comiter CV, Benson CJ, Capelouto CC, Kantoff P, Shulman L, Richie JP, Loughlin KR: Nonpalpable intratesticular masses detected sonographically. J Urol. 1995, 154:1367-1369. 10.1016/S0022-5347(01)66865-4

21. Curigliano G, Magni E, Renne G, De Cobelli O, Rescigno M, Torrisi R, Spitaleri G, Pietri E, De Braud F, Goldhirsch A: "Burned out" phenomenon of the testis in retroperitoneal seminoma . Acta Oncol. 2006, 45:335-336. 10.1080/02841860500401175

22. George SA, Al-Taleb A, Hussein S: Retrogressed (burned-out) testicular germ cell tumor disguising as duodenal gastrointestinal stromal tumor. Onc Gas Hep Rep. 2015, 4:114-115. 
10.4103/2348-3113.152335

23. Gurioli A, Oderda M, Vigna D, Peraldo F, Giona S, Soria F, Cassenti A, Pacchioni D, Gontero P: Two cases of retroperitoneal metastasis from a completely regressed burned-out testicular cancer. Urologia. 2013, 80:74-79. 10.5301/RU.2013.10768

24. Hu B, Shah S, Shojaei S, Daneshmand S: Retroperitoneal lymph node dissection as first-line treatment of node-positive seminoma. Clin Genitourin Cancer. 2015, 13:265-269.

10.1016/j.clgc.2015.01.002

25. Jaber S: Retroperitoneal mass and burned out testicular tumor. Saudi J Kidney Dis Transpl. 2010, 21:542-543.

26. Kebapci M, Can C, Isiksoy S, Aslan O, Oner U: Burned-out tumor of the testis presenting as supraclavicular lymphadenopathy. Eur Radiol. 2002, 12:371-373. 10.1007/s003300101038

27. Leleu O, Vaylet F, Debove P, Levagueresse R, L'her P: Pulmonary metastasis secondary to burned-out testicular tumor. Respiration. 2000, 67:590. 10.1159/000029579

28. Lopez JI, Angulo JC: Burned-out tumour of the testis presenting as retroperitoneal choriocarcinoma. Int Urol Nephrol. 1994, 26:549-553. 10.1007/BF02767657

29. Mesa H, Rawal A, Rezcallah A, Iwamoto C, Niehans GA, Druck P, Gupta P: "Burned out" testicular seminoma presenting as a primary gastric malignancy. Int J Clin Oncol. 2009, 14:7477. 10.1007/s10147-008-0804-0

30. Onishi K, Tomioka A, Maruyama Y, Otani T, Ishikawa H, Fujimoto K: Burned-out testicular tumor diagnosed triggered by paraneoplastic neurological syndrome; a case report (Article in Japanese). Hinyokika Kiyo. 2014, 60:651-655.

31. Perimenis P, Athanasopoulos A, Geraghty J, Macdonagh R: Retroperitoneal seminoma with 'burned out' phenomenon in the testis. Int J Urology. 2005, 12:115-116. 10.1111/j.14422042.2004.00987.x

32. Peroux E, Thome A, Geffroy Y, Guema BN, Arnaud FX, Teriitehau CA, Baccialone J, Potet J: Burned-out tumour: a case report. Diagn Interv Imaging. 2012, 93:796-798. 10.1016/j.diii.2012.03.023

33. Preda O, Nicolae A, Loghin A, Borda A, Nogales FF: Retroperitoneal seminoma as a first manifestation of a partially regressed (burnt-out) testicular germ cell tumor. Rom J Morphol Embryol. 2011, 52:193-196.

34. Qureshi JM, Feldman M, Wood H: Metastatic "burned-out" germ cell tumor of the testis . J Urol. 2014, 192:936-937. 10.1016/j.juro.2014.06.038

35. Rzeszutko M, Rzeszutko W, Nienartowicz E, Jeleń M: Paratesticular localization of burned out non-seminomatous germ cell tumor--NSGCT: a case report. Pol J Pathol. 2006, 57:55-57.

36. Sahoo PK, Mandal PK, Mukhopadhyay S, Basak SN: Burned out seminomatous testicular tumor with retroperitoneal lymph node metastasis: a case report. Indian J Surg Oncol. 2013, 4:390-392. 10.1007/s13193-012-0207-6

37. Suzuki K, Yoshida T, Inoue M, Yoshida I, Kurokawa K, Suzuki T, Imai K, Yamanaka H: Growing mediastinal metastatic tumour in a patient with burned out testicular cancer . Int Urol Nephrol. 1998, 30:181-184. 10.1007/BF02550574

38. Yamamoto H, Deshmukh N, Gourevitch D, Taniere P, Wallace M, Cullen MH: Upper gastrointestinal hemorrhage as a rare extragonadal presentation of seminoma of testis. Int J Urol. 2007, 14:261-263. 10.1111/j.1442-2042.2007.01685.x

39. Yucel M, Kabay S, Saracoglu U, Yalcinkaya S, Hatipoglu NK, Aras E: Burned-out testis tumour that metastasized to retroperitoneal lymph nodes: a case report. J Med Case Rep. 2009, 3:7266. 10.1186/1752-1947-3-7266

40. Yucel M, Saracoglu U, Yalcinkaya S, Hatipoglu NK, Kabay S, Dedekarginoglu G: Burned-out testicular seminoma that metastasized to the prostate. Cent European J Urol. 2009, 62:195197.

41. Rodriguez S, Jafer O, Goker H, Summersgill BM, Zafarana G, Gillis AJ, van Gurp RJ, Oosterhuis JW, Lu YJ, Huddart R, Cooper CS, Clark J, Looijenga LH, Shipley JM: Expression profile of genes from $12 p$ in testicular germ cell tumors of adolescents and adults associated with $\mathrm{i}(12 \mathrm{p})$ and amplification at 12p11.2-p12.1. Oncogene. 2003, 22:1880-1891. 10.1038/sj.onc.1206302

42. Poorly differentiated neoplasms of unknown primary site . (2015). Accessed: August 25, 2015: http://www.aboutcancer.com/cup_poor_neo_utd_507.htm.

43. Vossen CY, Hoffmeister M, Chang-Claude JC, Rosendaal FR, Brenner H: Clotting factor gene polymorphisms and colorectal cancer risk. J Clin Oncol. 2011, 29:1722-1727.

10.1200/JCO.2010.31.8873 